\title{
Rereading Samuel's Silence in 1 Samuel 7:8
}

\begin{abstract}
1 Samuel 7:8 records a request made by the people of Israel to Samuel, asking him to pray to God for them. Although the aim of their request is made clear from the context, some aspects of the Hebrew syntax and word meanings do not easily fit the contextually understood meaning and are therefore often disregarded in the process of translation. The Hiphil verb חרשש, for example, which normally means 'be silent', is often translated as 'cease' and sometimes as 'be deaf'. In addition, the preposition מן, 'from', is often translated as 'for' and is understood to indicate the beneficiary of the verb it precedes rather than function as the prepositional object of the verb it follows, as would be expected. I suggest that a very simple adjustment to the interpretation of this preposition may allow for a more straightforward reading and translation of the verse.
\end{abstract}

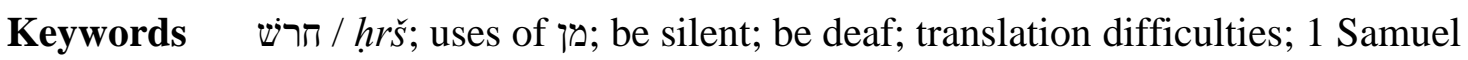

\section{Introduction}

Interpreters of 1 Samuel 7:8 face both lexical and syntactic difficulties in the Hebrew text, and as a result many render the verse according to its contextually understood meaning rather than remain bound to the difficult structure of the Hebrew.

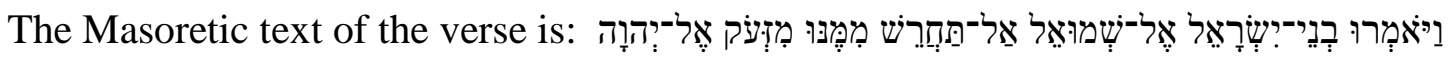

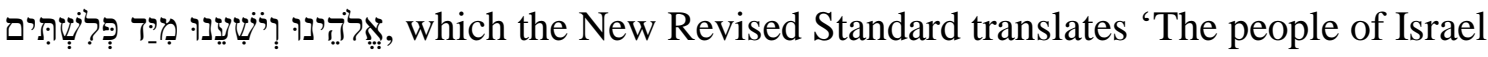
said to Samuel, "Do not cease to cry out to the LORD our God for us, and pray that he may 
save us from the hand of the Philistines"'. ${ }^{1}$ The textual difficulty is found in the people's plea, which many modern translations convey as 'do not cease praying for us'. 2

Commentators have also traditionally taken this line, with translations such as 'Laß nicht ab für uns zu schreien zum Herrn unserem Gotte', ${ }^{3}$ or 'Rufe rastlos mit uns (?) laut zu deinem/unserem Gotte Jahwe'. ${ }^{4}$ Similarly: 'Ne cesse pas de crier vers Iahvé notre Dieu' ${ }^{5}$ and 'Ne cesse pas d'invoquer Yahvé notre Dieu.' ${ }^{6}$ This tradition of interpretation may reflect influence from the Vulgate: ne cesses pro nobis clamare ad Dominum Deum nostrum.

The surrounding context does make sufficiently clear that the Israelites, oppressed by the Philistines and desiring divine help, want Samuel to intercede for them, as he has in fact already promised to do (7:5). When the Philistines attack, the people are afraid and plead

\footnotetext{
${ }^{1}$ All subsequent English translations will be from the New Revised Standard Version, unless otherwise noted.

${ }^{2}$ The Revised Standard Version and the English Standard Version both read 'do not cease to cry out to the LORD our God for us', while the 1917 JPS translation and the Authorised (King James) Version have 'Cease not to cry unto the LORD our God for us'. The same sense is reflected in other modern European language translations. As a small sample, the French Louis Segond translation has 'Ne cesse point de crier pour nous à l'Éternel, notre Dieu', and in German both the Schlachter and Redivierte Lutherbibel have 'Laß nicht ab, für uns zu dem HERRN, unserem Gott, zu rufen'.

${ }^{3}$ Carl Friedrich Keil, Die Bücher Samuels (Biblischer Commentar über die prophetischen Geschichtsbücher des Alten Testaments, vol. 2; Leipzig, 1875), p. 63.

${ }^{4}$ Wilhelm Caspari, Die Samuelbücher (KAT 7; Leipzig, 1926), p. 90. The question mark is present in Caspari's original text and indicates his uncertainty as to how to translate ממנו He has used the adverb 'rastlos' ('unremittingly, ceaselessly') instead of the command 'cease not'.

${ }^{5}$ Paul Dhorme, Les Livres de Samuel (Paris, 1910), p. 67.

${ }^{6}$ R. de Vaux, Les Livres de Samuel (Paris, 1961), p. 47.
} 
with Samuel that he cry out to God for them, which he does (7:7-9). The LORD then answers Samuel's prayer, and the Philistines are defeated before the Israelites (7:9-11).

The expression of the people's plea, however, is not as straightforward as translations imply. It is expressed by the negative command אַל־תחמִרִש ('do not be silent'), followed by

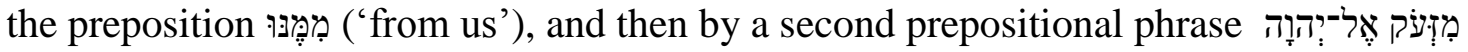
אֶלה ('from crying out to the LORD our God'). By rendering the request as 'do not cease praying for us', translators alter the usual meanings both of the verb הרש (from 'be silent' to 'cease') and of the preposition (from 'from' to 'for'). They also relocate the first preposition, ממנו, translating it as if it followed rather than preceded the second prepositional phrase.

In this paper I briefly summarise the attested meanings of חרשש, in particular when followed by the preposition מן, and survey different translation approaches. Finally, I propose a minor adjustment in interpretation that may resolve both the semantic and the syntactic difficulties of the verse.

\section{Semantic Background: Meanings of חריש}

Words formed from the root(s) חרש cover a wide range of semantic domains: from artisanry and engraving to ploughing, deafness and silence, magic and more. Only those words related to silence and deafness, however, are relevant for this brief study. 
As an adjective and noun, חריש unambiguously means 'deaf', a meaning confirmed by statements describing the חריש as not hearing or as having bound ears. ${ }^{7}$ Verbs formed from the same root, however, show more variation in meaning. The Qal, used seven times in biblical texts, can mean either 'be deaf' or 'be silent', while the single Hithpael reference could refer either to holding still or to being silent or quiet. ${ }^{8}$ The Hiphil, by far the most common with thirty-nine occurrences, primarily means 'be silent', a meaning established by parallel and explanatory phrases that refer, for example, to putting a hand on the mouth, closing the lips, not saying a word or not finding a word. ${ }^{9}$ The silence to which Hiphil חרש refers is often related to communication, ${ }^{10}$ though it can also be used figuratively to

\footnotetext{
${ }^{7}$ Ps 38:14 (Engl. 13): ואני כחרש לא אשמע ('But I am like the deaf, I do not hear’) and Ps 58:5 (Engl. 4): כמו־ פתן חרש יאטם אזנו ('like the deaf adder that stops its ear').

לעזתים לאמר בא שמשון הנה ויסבו : ויארבו־לו כל־הלילה בשער העיר ויתחרשו כל־הלילה לאמר עד־אור הבקר והרגנהו , which the NRSV translates 'The
} Gazites were told, "Samson has come here." So they circled around and lay in wait for him all night at the city gate. They kept quiet all night, thinking, "Let us wait until the light of the morning; then we will kill him."'.

${ }^{9}$ In Jdgs 18:19 a priest is told החחרּש שים-ידך על־פיך ('Keep quiet! Put your hand over your mouth'). In 2 Kgs 18:36 the people's silence (Hiph. חרש ) under Sennacherib's siege is paralleled by the phrase 'did not answer':

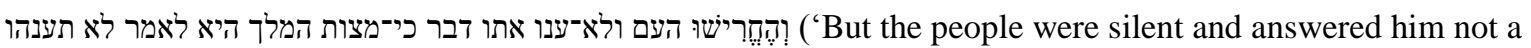
word, for the king's command was, "Do not answer him."'); cf. also the nearly identical Isa 36:21 וַיְחרישישוּ ולאאד ענו אתו דבר כי־מצות המלך היא לאמר לא תענהו 'But they were silent and answered him not a word, for the king's command was, "Do not answer him."'). In Prov 17:28 the Hiphil of הרש אויל : גו מֵחְרִיש חכם יחשב אטם שפתיו נבון they are deemed intelligent'). Finally, the Hiphil of חרש is equated to not finding a word to say in Neh 5:8:

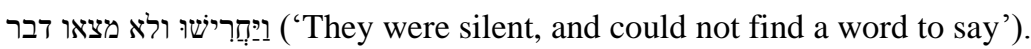

${ }^{10}$ Silence in the realm of communication can refer either to a silence that allows someone to speak, thus promoting communication (as in Job 33:31, 33), or to a silence that inhibits or prevents communication (as in Gen 24:21 and Ps 32:3). 
indicate the restraint of an expected action. ${ }^{11}$ Based on these other uses of the Hiphil, the

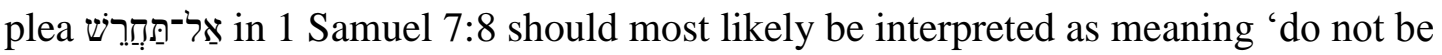
silent'.

\section{a Hiphil מל מר with}

The Hiphil of מרש only in 1 Samuel 7:8 and two additional references. One of these is Job 13:13, in which Job demands that his friends be silent 'from him', that is, that they cease speaking their 'proverbs of ashes' (13:12), so that Job himself might be able to speak. He commands: הַחְרִישוּ ממני ואדברה־אני ויעבר עלי מה me have silence, and I will speak, and let come on me what may'). The second example is found in Jeremiah 38:27, in which the officials who had been interrogating Jeremiah finally are silent 'from him' after he successfully deflects their questioning: ויבאו כל־השרים

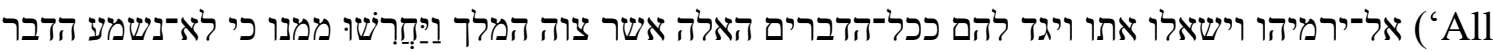
the officials did come to Jeremiah and questioned him; and he answered them in the very words the king had commanded. So they stopped questioning him, for the conversation had not been overheard'). In both of these references חרש מן refers to a cessation of speech by the subject of חרש with the object of the preposition מן. Although it would be possible for the preposition מן to indicate separation or motion away from in Jeremiah 38, this cannot be the sense in Job 13, where Job expresses his desire to be heard by his friends and would thus not be asking them to depart from him.

\footnotetext{
${ }^{11}$ One such restrained action referred to by Hiphil חרש is divine judgement, for which see Ps 50:21, Isa 42:14 and Hab 1:13. For other contexts in which חרש refers to a lack of expected action, see Exod 14:14 and 2 Sam 19:11.
} 
If 1 Samuel 7:8 is interpreted in light of these two references, the subject of חשרש, that is, Samuel, is commanded not to cease speaking with the object of the preposition understood as the people. Their plea would mean 'Do not be silent from us' or 'do not cease speaking with us'. This interpretation does not easily fit the context, however, as their desire is not that Samuel continue speaking with them, but that he not cease speaking with God on their behalf.

מן Placement of

A further difficulty with the interpretation of 1 Samuel 7:8 relates to the placement of the two prepositional objects with ממנו מן. ממו, 'First ifrom us', and then מזעק 'from crying out'. This order of phrases would naturally lead to an interpretation such as 'do not be silent from us, from crying out to the LORD our God'. Asking Samuel not to be silent from the people, however, is certainly not equivalent to asking him not to be silent from God. As a result of this difficulty, interpretation of the request is commonly adjusted to 'do not cease to cry out for us'. This interpretation reverses the order of the prepositional phrases by placing the second phrase, 'from crying out', immediately after the verb 'be silent' (as if the text read אל־תחרש מזעק), while the first prepositional phrase, 'from us', is translated as if it followed rather than preceded the verb 'cry out'.

\section{Interpretation of מן}

Another difficulty with the standard interpretation is that the preposition which usually indicates separation, removal from, or 'motion away from something', ${ }^{12}$ is instead interpreted as a preposition indicating the beneficiary of an action: 'praying for us'. The

\footnotetext{
${ }^{12}$ BDB defines as 'expressing the idea of separation' (Oxford, 1907), p. 577. See also Gesenius-Kautzsch $\S 119$ v, x; Joüon-Muraoka $§ 1333$.
} 
preposition בעד, however, more commonly indicates prayer on someone's behalf. It is used תפלה פל פלל ('to pray') or the related noun ('prayer'), ${ }^{13}$ and twice in this same chapter בעד indicates the beneficiaries of Samuel's prayer: first in 7:5, when he says he will pray for the people to the LORD (-) יהוה ויזעק (י) and then in 7:9, where he is reported to have cried out to the LORD for Israel שמואל אל־יהוה בעד ישראל 12:23 to indicate the people as the beneficiary of Samuel's prayer: חלילה לי מחטא ליהוה מחדל להתפלל בעדכם ('far be it from me that I should sin against the LORD by ceasing to pray for you'). The preposition מן, however, is not used elsewhere to indicate the beneficiary of prayer.

\section{b Q Q Q Q}

It is worth considering whether the Qal of חרש might make better sense in this passage, as the consonantal text אל־תחרש would be identical as a Qal or a Hiphil. ${ }^{14}$ The Qal of חרש,, as mentioned above, can mean either 'be deaf' or 'be silent'. ${ }^{15}$ It appears five times in the

\footnotetext{
${ }^{13}$ These references are: Gen 20:7; Num 21:7; Deut 9:20; 1 Sam 7:5; 12:19, 23; 1 Kgs 13:6; 2 Kgs 19:4; Job 42:10; Ps 72:15; Isa 37:4; Jer 7:16; 11:14; 14:11; 29:7; 37:3; 42:2, 20.

${ }^{14}$ Caspari also makes this suggestion. His note on חרש in 1 Samuel 7:8 reads 'Qal von Gott Ps 28,1 ist durch die Umstände gegen Mißdeutung geschützt; Jer 38, 27 Hi vom Menschen; auch hier soll Qal für einen Menschen zu bedeutend lauten' (Caspari, Die Samuelbücher, p. 90). He does not, however, discuss the meaning of חרש in these passages, nor does he explain how he arrived at his translation 'call unceasingly with us' ('Rufe rastlos mit uns (?) laut zu deinem/unserem Gotte Jahwe', with the bracketed question mark included in his text), which does not convincingly represent the meanings of either ממנו or מרש

${ }^{15}$ It clearly means 'be deaf' in Mic 7:16, where ears are said to be deaf (אזניהם תחרשנה), but it must mean 'be silent' in Ps 50:3, where God, who comes in judgement of fire and storm, is said not to יבא אלהינו ואל־ :חרש יחרש אש־לפניו תאכל וסביביו נשערה מאד. God's activities in Ps 50 include speaking and summoning the earth (v. 1) with a devouring fire and mighty tempest around him (v. 3), calling to the heavens and the earth in order to judge his people (v. 4) and proclaiming to his people that he will speak and testify against them (v. 7). The
} 
Psalms as a negative command addressed to God, in the same consonantal form as in 1 Samuel 7:8. In some of these Psalms references the verb חרש is parallel to ideas of quiet and rest, and therefore more likely means 'be silent', while in others חרש is placed in opposition to verbs of hearing, thus more likely meaning 'be deaf'. ${ }^{16}$

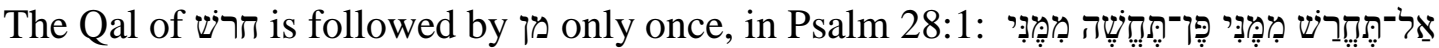

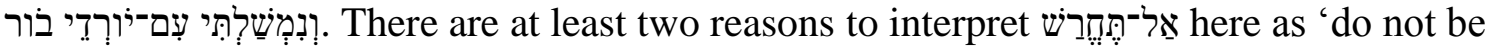
deaf' rather than 'do not be silent'. First, the following verse contains the command קול תחנוני ('hear the voice of my supplication'), which provides a fitting positive parallel to the negative command 'do not be deaf to me'. Second, the negative command is followed immediately by the subordinate clause פן־תחשה ממני ('lest you be silent from me'), which

portrayal of divine action and speech in this psalm contrasts with silence rather than with deafness, strongly suggesting that Qal חרש in this verse means 'be silent'. This 'silence' does not refer only to a lack of noise, but also can represent a lack of response or restraint from action. This meaning has also been identified by $\mathrm{G}$. Eidevall, who describes the meaning of Qal חרש not only as 'be deaf' but also as 'be still (idle, passive, silent)'. See G. Eidevall, 'Sounds of Silence in Biblical Hebrew: A Lexical Study', VT 62 (2012), p. 167. ${ }^{16}$ In my analysis, אל־תחרש in Pss 35:22, 83:2 (Engl. 1) and 109:1 is more likely to mean 'do not be silent', based either on nearby parallels or on the psalmist's request for a clear response from God. (For Ps 109:1, admittedly, an argument could be made for the meaning 'do not be deaf', based on the reference to the mouths of the wicked in the following verse. On balance, however, as the bulk of the psalm consists of pleas for divine vengeance against enemies, I find more convincing the interpretation 'do not be silent'.) In Pss 28:1 and 39:13 (Engl. 12), in contrast, אל־תחרש more likely means 'do not be deaf', as it is used in parallel to positive commands to hear. For a slightly different analysis of Qal חרש in these verses, see Eidevall, 'Sounds of Silence', pp. 166-67. He argues that the primary definition of Qal חרש is 'be deaf', and he suggests this meaning also for Pss 83:2 and 109:1. My interpretation of חרש as 'be silent' in these two verses is based more on the surrounding context than on any presumed basic meaning of the Qal, but given its proven dual semantic nature, either interpretation is indeed possible. 
suggests that the undesired silence (תחשה) of the second clause would be a result of the deafness (תחרש) of the first. Some translators, (mis)interpreting the first verb חרש as 'be silent', add the conditional 'if' before the second clause with פן: 'do not be silent, lest if you be silent', thereby making the two verbs not only parallel, but also synonymous. ${ }^{17}$ The conjunction ('lest'), however, usually warns against an undesirable result that would follow as a natural consequence of the action preceding פן, and it is thus unlikely to connect two parallel or synonymous verbs. ${ }^{18}$ The psalmist's request in $28: 1$ is therefore best interpreted as 'do not be deaf to me, lest (as an undesirable consequence) you be silent to me (and not answer me)'.

If חרשש מן in 1 Samuel 7:8 is reanalysed as a Qal in light of the use of מל־תרש ממנ in Psalm $28: 1$, it would mean 'do not be deaf to (lit. 'from') us'. ${ }^{19}$ It would imply that the people talking to Samuel want to be heard by him, a logical interpretation in the context. It becomes more difficult, however, to relate the same verb meaning 'be deaf' to the second prepositional object, 'from crying out to the LORD our God', which would create the

\footnotetext{
${ }^{17}$ The Authorised Version, for example, translates the beginning of the verse 'be not silent to me: lest, if thou be silent to me...'; the German Einheitsübersetzung has 'Wende dich nicht schweigend ab von mir! Denn wolltest du schweigen...'.

${ }^{18}$ expresses 'a fear or precaution' and can be used in 'an appeal to do or not to do an action' (in this case, not to חרש), 'by which something may be prevented' (in this case, חשה) (GK $\$ 152$ w). The 18th edition of Gesenius's lexicon defines פן as: 'wenn eine Handlung vorausgeht, die eine andere, zu befürchtende, hindern soll' (vol. 4, 2007, p. 1058). HALOT defines two meanings of פן with imperfect as: 1) 'so that not, lest' and 2) 'or else, in case, perhaps', used with the purpose of 'rejection of a consequence which might be possible' (2001, pp. 936-937). In each case, it is clear that indicates a contrast, not synonymity, between two verbs. ${ }^{19}$ Cf. S.R. Driver, Notes on the Hebrew Text and the Topography of the Books of Samuel, $2^{\text {nd }}$ ed. (Oxford, 1913), p. 64.
} 
nonsensical 'do not be deaf from crying out'. If אל־תחרש is translated as 'do not be deaf', then, another verbal idea must be supplied for מזעק, either from the preposition מן itself (suggesting departure from, cessation, or simply negation) or by reinterpreting the verb מזעק in relation to mean 'be silent from crying out'. Examples of each approach will be considered below in the survey of different interpretations.

\section{History of Interpretation: Translations of 1 Samuel 7:8 \\ a Cease}

By far the most common modern interpretation of אל־תחרש in this verse is that mentioned at the start: 'do not cease from crying out to the Lord our God for us'. As has been shown, this is not an attested meaning of חרש elsewhere, and the translation both reinterprets and relocates the first prepositional object ממנו.

\section{b Be Silent}

The Septuagint preserves the sense of being silent implied by חith with $\mu$ ì

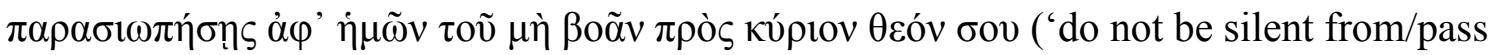
over us in silence, with the result that you not cry out to the LORD your God'), ${ }^{20}$ though it

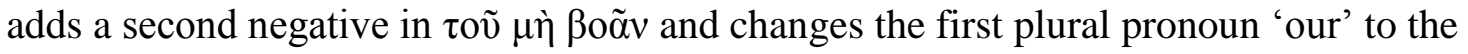
לא : second singular 'your'. The Targum also translates with a verb meaning 'be silent' de not be silent from us, from praying before the LORD our God'). Manuscript variants for תשתיק, תשפסוק are, 'to silence', and come to an end,

\footnotetext{
${ }^{20}$ My translation. The NETS translation of this phrase is 'Do not omit mention of us so as not to cry to the Lord, your God'. Albert Pietersma and Benjamin G. Wright (eds.), A New English Translation of the Septuagint (Oxford, 2007), p. 253.
} 
to break away from someone'. ${ }^{21}$ These variants reflect the different possibilities of interpreting חרש as either 'be silent' or 'stop speaking with'. The Peshitta uses the cognate root (عלa) to translate חריש ('Do not be silent from us, to pray for us before the Lord our God'). ${ }^{22}$

Some more recent translations also interpret הרنש in this verse as 'be silent'. In the 1912 ICC, for example, Smith translates: 'Do not be silent, so as not to cry to Yahweh thy God', seemingly omitting altogether the preposition ממנו from his translation. ${ }^{23}$ Klostermann translates: 'verstumme nicht unserthalben daß du nicht flehest zu Jahwe unserem Gotte', translating ממנו as 'on our behalf'. ${ }^{24}$ According to this interpretation, Samuel's silence before the people would also cause him to be silent before God, although the implied causal connection seems neither textually nor contextually supported.

\section{c Refuse or Deny}

חרש has also been interpreted figuratively in this verse as refusal. McCarter translates: 'Do not refuse to cry out for us to Yahweh, your god', ${ }^{25}$ adding a sense of volition to the similar

\footnotetext{
${ }^{21}$ My translation. The text, variants and glosses are from the on-line Comprehensive Aramaic Lexicon Project at http://cal1.cn.huc.edu (accessed 1 April 2015).

${ }^{22}$ My translation. The text is from the on-line Comprehensive Aramaic Lexicon Project at http://cal1.cn.huc.edu (accessed 1 April 2015).

${ }^{23}$ Henry Preserved Smith, The Books of Samuel (ICC; Edinburgh, 1912), p. 53.

${ }^{24}$ Klostermann additionally offers the more literal: 'schweige nicht von uns weg, vom Schreien', the sense of which he describes as: 'in dem du deine gesetzgebende Rede jetzt vor dem Kriegslärm unterbricht, verstumme doch nicht so völlig in unsren Angelegenheiten, daß du auch die Gebetsrede an Jahwe für uns aufgebest.’ August Klostermann, Die Bücher Samuelis und der Könige (Nördlingen, 1887), p. 23.

${ }^{25}$ P. Kyle McCarter, Jr., 1 Samuel, (AB 8; Garden City, 1980), p. 140.
} 
translation 'do not cease praying for us'. Nowack translates with 'Versage dich uns nicht, daß du nicht zu Jahve, unserm Gott, schreien solltest, ${ }^{26}$ which expresses a desire that Samuel not fail them by denying them his prayers.

\section{d Interpretation of wרש with Multiple Verbs}

Some translators and commentators reflect the multivalency of חשרש by translating with more than one verb in the target language. Schulz uses the two verbs 'abandon' and 'cease' to convey the meaning of חרש: 'Verlaß uns nicht! Höre nicht auf zu schreien zu Jahwe, unserem Gotte'. ${ }^{27}$ The 1985 JPS translation has 'Do not neglect us and do not refrain from crying out to the LORD our God', first figuratively interpreting חרש מן as 'neglect', then seemingly retranslating it as 'refrain from' in relation to the second prepositional object. Another multi-verb translation is the Einheitsübersetzung, with: 'Kehr dich nicht schweigend von uns ab, und hör nicht auf, zum Herrn, unserem Gott, zu rufen' ${ }^{28}$ The first phrase, 'do not silently turn away from us', reflects the sense of חרש as 'be silent' and the sense of motion away from implied by the preposition מן. The second phrase, 'do not cease to cry to the Lord our God', seems to reinterpret חרש as 'cease' in relation to the second prepositional phrase, מזעק אל־יהוה אלהינו. As a final example, the French Traduction CEcuménique has: 'Ne reste pas muet! Ne nous abandonne pas! Crie vers le SEIGNEUR, notre Dieu'. ${ }^{29}$ Although the phrase אל־תחרש ממנו does not seem to be directly translated, it

\footnotetext{
${ }^{26}$ W. Nowack, Richter, Ruth u. Bücher Samuelis (HAT; Göttingen, 1902), p. 33.

${ }^{27}$ Alfons Schulz, Die Bücher Samuel (Münster in Westf., 1919), p. 113. He comments: 'Zu dem Ausdruck "verlasse uns nicht" - "lasse nicht ab von uns" vgl Jer 38.27', where the Hiphil of חרש is used with מן to indicate leaving someone alone (p. 117).

28 The German Einheitsübersetzung der Heiligen Schrift (Stuttgart, 1980).

${ }^{29}$ French Traduction Ecuménique de la Bible (Paris, 1988).
} 
is most clearly represented by the plea 'do not abandon us', while the second prepositional phrase regarding prayer is turned into a positive command: 'Cry out to the LORD our God'. The first plea, 'Do not remain mute/silent', represents another possible sense of חרש, though in this translation it is disconnected from the prepositional phrases that follow it in the Hebrew.

The multiple verbs used in these translations effectively represent the various possible senses of אל־תחרש in relation to the two prepositional phrases with מן. The solution of giving a single verb a double semantic role in one sentence, however, with a different meaning for each prepositional phrase, is not ideal, nor is it likely in a non-poetic text reporting direct speech.

\section{e Interpretation of is with Verbal Implications}

Another approach to dealing with the difficulties of this verse is to interpret the preposition מן as supplying a separate verbal idea in relation to the second prepositional object, 'cry out'. Some take simply as a negative, while others add to it a contextually inferred sense of causality ('so as not to'). Budde suggests that מן is used as a negative replacement for בעד, which is used in other verses on prayer. ${ }^{30}$ Segal too interprets מזעק as a negative:

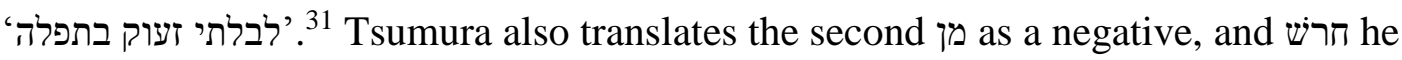
interprets as referring to both silence and distance: 'Do not be silent and distant from us, not crying to the LORD our God'. ${ }^{32}$

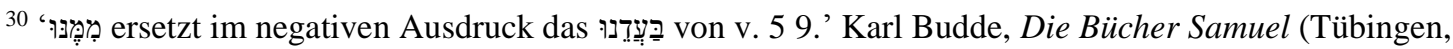
1902), p. 50.

${ }^{31}$ Moshe Tsvi Segal, The Books of Samuel (Jerusalem, 1956), p. 58.

${ }^{32}$ David Toshio Tsumura, The First Book of Samuel (Grand Rapids, Michigan, 2007), pp. 233, 235.
} 
Others interpret the meaning of חרש differently in relation to the first מן. S.R. Driver, for example, translates the first clause as 'do not be deaf (turning) from us'. He points to Psalm 28:1 for comparison, where חרש is a Qal, but he does not explicitly suggest that the verb here should be considered a Qal. ${ }^{33}$ For the second prepositional phrase Driver suggests the translation 'so as not to cry (lit. away from crying)'. He attributes the verbal idea of cessation in this passage to the preposition מן alone, not connecting it closely with the meaning of the verb חרש. ${ }^{34}$ R. Klein interprets similarly, with aרש as 'be deaf' and the second מן as 'so as not to': 'Do not be deaf toward us, so as not to cry to Yahweh our God'. ${ }^{35} \mathrm{He}$ does not defend the translation as 'deaf', though he does associate this request

Tsumura distinguishes in his notes between the two uses of מן: identifying the first as 'from us' (noting that the 'basic meaning' of the preposition is 'distancing') and the second as a 'privative min' meaning 'being away from', though he also describes it as 'a resultive phrase', which does not so clearly come out in his translation.

${ }^{33}$ On this point he refers to GK $\S 119 \mathrm{ff}$, which describes uses of מן after a verb as creating a pregnant construction. Gesenius here translates the phrase חרש מן in Ps 28:1 as 'to be silent from one (to turn away in silence)'. Driver does not address the semantic difference between his own translation, 'be deaf from', and that of Gesenius, 'be silent from' (Driver, Notes, p. 64).

${ }^{34}$ Driver (Notes, p. 64) refers to GK $\$ 119$ y, which contains examples of מן before an infinitive in which 'the idea of precluding from anything is only indirectly contained in the preceding verb'. The examples cited are: Gen 27:1, in which Isaac's eyes are dim 'from seeing' (מָרָאת), and Isa 33:15, in which one stops his ears from

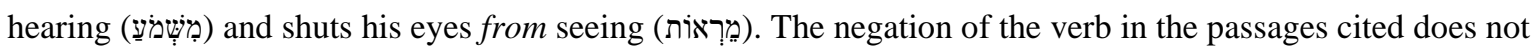

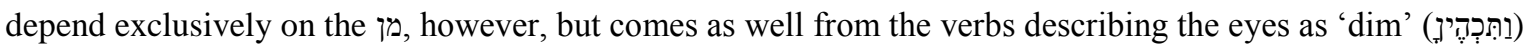

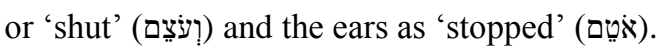

${ }^{35}$ Ralph W. Klein, 1 Samuel, $2^{\text {nd }}$ ed. (WBC 10; Nashville, 2008), p. 63. 
with those of the psalmist, who asks God not to be deaf to him but to answer his plea. ${ }^{36}$ Klostermann also translates the second מן with a causal sense: 'daß du nicht flehest', ${ }^{37}$ as does Schulz with 'so daß du nicht mehr schreiest'. ${ }^{38}$

While followed by an infinitive can imply inability, lack or cessation, the additional sense of result or equivalence in these translations is only inferred from an interpretation of the context. Samuel's silence 'from' the people is assumed either to cause his silence from God or to be equated with it: 'do not be silent from us' (or, if repointed as a Qal, 'do not be deaf to us') and — as a result of this silence/neglect, or somehow as equivalent to it 'cease praying for us'. The nature of the connection between the two clauses is not entirely clear, however, and translators rely heavily on inference to supply the second מן with this semantic role. ${ }^{39}$ In the broader context of the chapter, in which Samuel has already

\footnotetext{
${ }^{36}$ Klein writes: 'The people turned to Samuel and asked that he not ignore or be deaf to their need. In the Psalter it is often God who seems to be deaf to need (e.g. Pss 28:1; 35:22), but Josh 10:8 reports another petition directed to a human leader of Holy War that he not neglect his responsibilities to the people at such a time. Ironically the Hebrew word for "being deaf" is used in Exod 14:14 to describe the people's silence and inaction as Yahweh fights for them' (Klein, 1 Samuel, p. 67). Contrary to this claim, however, חרש in Exod 14:14 is a Hiphil meaning 'be silent', not a Qal meaning 'be deaf'.

${ }^{37}$ Klostermann, Die Bücher Samuelis, p. 23.

${ }^{38}$ Schulz helpfully attempts to explain the causal connection inherent in the second מן, though his explanation relies on the interpretation of חרש as 'abandon' ('im Stich lassen'): 'Der folgende Inf. mit מן hat den Sinn: “so daß du nicht mehr schreiest”. Wenn Samuel sie im Stiche läßt, dann wird die Folge sein, daß er nicht mehr für sie betet. Da sie der Übermacht der Philister nicht gewachsen sind, so wenden sie sich um Hilfe an Jahwe' (Schulz, Die Bücher Samuel, p. 117).

${ }^{39}$ The syntax of 1 Sam 12:23 (חלילה לי מחטא ליהוה מחדל להתפלל בעדכם), with two verbs used in combination to indicate the cessation of prayer (חדל להתפלל), is much clearer, and the preposition מן before the verb does not carry the same (questionable) semantic weight.
} 
promised to pray for the people (ואתפלל בעדכם אל־יהוה in 7:5), it seems unlikely that his willingness to cry out to God on their behalf should now depend on his hearing — that is, his not being deaf to - their plea.

\section{Summary Analysis}

It should be clear by now that interpreters of 1 Samuel 7:8 have rendered the text in ways not entirely conforming to the Hebrew syntax because the contextually inferred meaning of the verse does not readily correspond to its syntax. While some have taken the approach of doubly translating חרש, more commonly translators have adjusted the meaning of חרש from 'be silent' to 'cease' and have altered both the location and the meaning of the first prepositional object ממנו ('from us'), relocating it to a position after the second prepositional object מזעק ('from crying out') and reinterpreting it as indicating a beneficiary ('for us') rather than its usual sense of 'from' or separation from.

If the usual meaning of the verb חרש as 'be silent' is maintained, along with the placement and expected meaning of the prepositional phrases 'from us' and 'from crying out', the difficulty is that the prepositional phrases relate to the verb differently, the first referring to Samuel's silence from the people and the second referring to the silencing of Samuel's prayer to God. One very simple solution may resolve this difficulty.

\section{Proposal for a New Reading}

The preposition ממנו, which has traditionally been analysed as having a first-person plural suffix ('from us'), is identical in form to the same preposition with a third-person masculine singular suffix ('from him'). If ממנו in this verse is read as the latter, the people's request could be interpreted as 'do not be silent from him', that is, God, with the third- 
person pronominal suffix referring proleptically to 'the LORD our God' in the next phrase. ${ }^{40}$ Both prepositional phrases would then relate to the verb in the same way, both reflecting the people's desire that Samuel not be silent from God but intercede on their behalf. The second prepositional phrase 'from crying out (מזעק) to the LORD our God' would be a further elaboration on their request that Samuel not be silent. ${ }^{41}$

This solution requires no change at all to the text, yet may solve the difficulties of the traditional interpretations. חרש does not need to be reinterpreted simply as 'cease', a meaning it does not have elsewhere, but can be interpreted as 'cease speaking with' in line with the other two cases of Hiphil חרש plus מן חיש The semantic and syntactic difficulties

\footnotetext{
40 The proleptic pronoun, if unexpected, is certainly not impossible, and is in any case less jarring than the adjustments made by translators in common interpretations of the verse. There are, in fact, quite a few cases of a proleptic pronominal suffix on a preposition, particularly in cases of apposition. See, for example: Num $32: 33$ (ויתן להם משה לבני־גד ולבני ראובן ולחצי שבט מנשה בן־יוסף), Jdgs 21:7 (מה־נעה להם לנותרים לנשים), Jer 51:56 (ומהם מן־בני שמעון), 1 Chron 4:42), and 2 Chron 26:14 (ויכן להם עליה על־בל). For other examples, see J-M §146 e and GK $\$ 131$ n. See also E. König, Historisch-Comparative Syntax der Hebräischen Sprache (Leipzig, 1897), §340 1-o. König describes the function of this type of proleptic pronoun as 'weniger ein Mittel der Hervorhebung, als ein Product pleonastischer Ausdrucksweise, oder gar glossirender Erläuterung', which I believe also fits with my suggested interpretation of 1 Sam 7:8.

${ }^{41}$ Alternatively, the suffix on ממנו could be interpreted as an impersonal third-person referring forward to the infinitive זעק and the act of crying out: 'Do not be silent from it, that is, from crying out'. Though perhaps more attractive syntactically, this interpretation seems less likely on the lexical-semantic level, as elsewhere is used only for interpersonal communication.

42 חרש can refer to restraint from action or lack of initiation of action but is not generally used to refer to cessation, as other silence words are (such as דמם). In the two other cases of Hiphil מן wרש with, the emphasis is on the initiation of silence, that is, the beginning of the subject's silence which affects the object of מןj.
} 
ממנו with also be resolved with this reading, as it does not require that be reinterpreted as meaning 'for' rather than 'from'. Furthermore, ממנו does not need to be relocated to a position after ('cry out') as its object or beneficiary. Instead, the two prepositional phrases with מן function in parallel, each relating to חרש in the same way: with reference to Samuel's speaking with and prayer to God. The people's plea then fits contextually: 'do not be silent from (or 'cease speaking with') him, from crying out to the LORD our God, that he might save us from the hand of the Philistines'. 